\title{
KOMUNITAS SWASEMBADA BEBAS POLUSI KARBON DI RUSUN TANGERANG SELATAN
}

\author{
Hansen Jeremy Rahardjo ${ }^{1)}$, Suwandi Supatra ${ }^{2)}$ \\ 1)Program Studi S1 Arsitektur, Fakultas Teknik, Universitas Tarumanagara, hansen_rahardjo@yahoo.com \\ 2)Program Studi S1 Arsitektur, Fakultas Teknik, Universitas Tarumanagara, suwandis@dtt.untar.ac.id
}

Masuk: 03-07-2021, revisi: 13-08-2021, diterima untuk diterbitkan: 23-10-2021

\begin{abstract}
Abstrak
Ekologi bumi kian tahun kian memburuk, Suhu bumi telah meningkat 1,2 derajat celcius dari masa pra-industri. Perkembangan pesat manusia seakan-akan "mengorbankan" keseimbangan ekologi bumi ini. Pemanasan Global adalah salah satu masalah terbesar yang seluruh penghuni bumi harus turut bantu selesaikan bersama, tanpa solusi yang jitu dampaknya akan terasa pada 3 faktor berikut, yaitu food security (kelangkaan makanan, dll), water security (kelangkaan air bersih, dll) dan kesehatan kita (perubahan iklim, suhu, dll). Kegiatan terkecil kita sehari-hari pun berperan dalam permasalahan global warming ini. Faktanya sektor bangunan dan residensial berkontribusi hingga 6\% dari keseluruhan permasalahan ini, mulai dari penggunaan energi listrik, gas, hingga limbah yang kita hasilkan dari rumah setiap harinya berdampak besar bagi dunia. Masalahnya, kebutuhan residensial kedepannya akan lebih tinggi daripada sebelumnya seiring dengan pertumbuhan jumlah penduduk dunia. Melalui proyek ini, penulis mencoba mengubah konsep residensial yang saat ini ada, mengintegrasikan teknologi ramah lingkungan pada residensial, khususnya bagi lingkungan provinsi Jakarta sebagai ibukota negara Indonesia yang pertumbuhannya sangat cepat (sekitar $1 \%$ per tahun) saat ini sudah mencapai angka 10 juta penduduk (15 juta diperkirakan pada tahun 2030). Teknologi ramah lingkungan yang sudah ada diterapkan kedalam sebuah integrasi arsitektural yang juga menciptakan self-sustaining life bagi penghuninya (menghasilkan kebutuhan sendiri), dimana tidak hanya ramah lingkungan tetapi juga mengurangi biaya hidup sehari-hari penghuninya. Diharapkan agar bisa menjadi pelopor tren residensial masa depan kedepannya.
\end{abstract}

Kata kunci: global warming; Jakarta; ramah lingkungan; residensial.

\begin{abstract}
Earth's ecologies are getting worse every year, our earth's temperature has reached 1.2 degrees Celsius hotter than the pre-industrial times, the rapid development of humans seems to have "sacrificed" the ecological balance of earth. Global warming is one of the biggest problems that all inhabitants of the earth must help solve, we can feel its impact on especially the following 3 factors, namely food security (scarcity of food, etc.), water security (scarcity of clean water, etc.) and our health (change of climate, temperature, etc.). Small things such as our daily activities also play a big role global warming, where in fact the building and residential sector contributes up to $6 \%$ of this total problem, starting from the use of electrical energy, gas, to the waste that we produce from our homes every day. The problem is that along with times, of course, the number of people will continue to grow, residential needs in the future will be higher than ever before. Through this project, the author tries to change the residential concept that currently exists, integrating environmentally sustainable technology in residents, especially for the Jakarta area as the capital city of Indonesia, which is growing very fast (about 1\% per year) and has now reached 10 million people (15 million is estimated by 2030). The existing eco-friendly technology will be applied into an architectural integration that also creates a self-sustaining life for its residents (generating their own needs), which is not only environmentally friendly but also reduces the daily living costs of the residents. In hope that it can be a pioneer of future residential trends in the future.
\end{abstract}

Keywords: global warming; Jakarta; residential; sustainable. 


\section{PENDAHULUAN}

\section{Latar Belakang}

Pemanasan global (global warming) adalah suatu bentuk ketidakseimbangan ekosistem di bumi akibat terjadinya proses peningkatan suhu rata-rata atmosfer, laut, dan daratan di bumi. Saat ini, Jakarta adalah kota yang paling cepat tenggelam. Organisation for Economic and Cooperation Development (OECD) dalam Green Growth Policy Review (GPPR) 2019 mencatat, permukaan tanah area-area pesisir Jakarta turun sampai empat meter hanya dalam 40 tahun terakhir. Bahkan Joe Biden menyinggung masalah Jakarta yang tenggelam dalam kurun waktu 10 tahun pada pidatonya di Kantor Direktur Intelijen Nasional, Selasa (27/7/2021). Berbagai penelitian dan modeling, salah satunya dari Institut Teknologi Bandung (ITB), memprediksi lima tahun lagi, seperempat wilayah Jakarta akan dibanjiri air laut. Selain penurunan muka air tanah karena begitu padat terhuninya Jakarta, tenggelamnya Jakarta juga disebabkan kenaikan air laut akibat pemanasan global.

\section{Rumusan Permasalahan}

Jakarta sebagai ibukota Indonesia, memiliki tingkat penyalahgunaan lahan yang sangat besar, dimana lebih dari 85\% lahannya dimanfaatkan sebagai perumahan/ residensial (Badan Pengelola Lingkungan Hidup Daerah Provinsi DKI Jakarta, 2016), artinya kebutuhan penghijauan juga jauh dibawah rata-rata sebuah perkotaan yang sehat (min. $30 \%$ ) memperparah sumbangan karbon kota ini. Faktor kesalahan tata guna lahan ini juga menjadi faktor yang berperan dalam penobatan Indonesia sebagai negara penyumbang emisi greenhouse gas terbesar ke-4 di dunia pada 2015. Apabila kita biarkan gaya hidup seperti ini, dalam 50-100 tahun kedepan bumi diperkirakan akan mengalami kenaikkan suhu sebesar $5-6^{\circ} \mathrm{C}$, yang fatal bagi bumi kita.

\section{Tujuan}

Merubah konsep perumahan di kota Jakarta dengan menciptakan sebuah desain prototipe perumahan vertikal yang menerapkan teknologi ramah lingkungan di dalamnya, yang menciptakan sebuah siklus karbon tertutup. Desain ramah lingkungan ini juga meng-komplemen kehidupan swasembada (mandiri) masyarakat di dalamnya yang memenuhi segala kebutuhannya sendiri melalui teknologi yang disediakan. Target incaran utama untuk proyek eksperimental ini tentunya masyarakat kota Jakarta terutama bagi kelompok menengah di Jakarta (perkembangan tercepat), yang akan sangat sulit untuk mempunyai rumah di Jakarta dengan harga tanah yang begitu tinggi.

Tabel 1. Pertumbuhan Penduduk Jakarta, Tingkat Pendapatannya

\section{JAKARTA}

Rumah menjadi kebutuhan primer setiap orang.
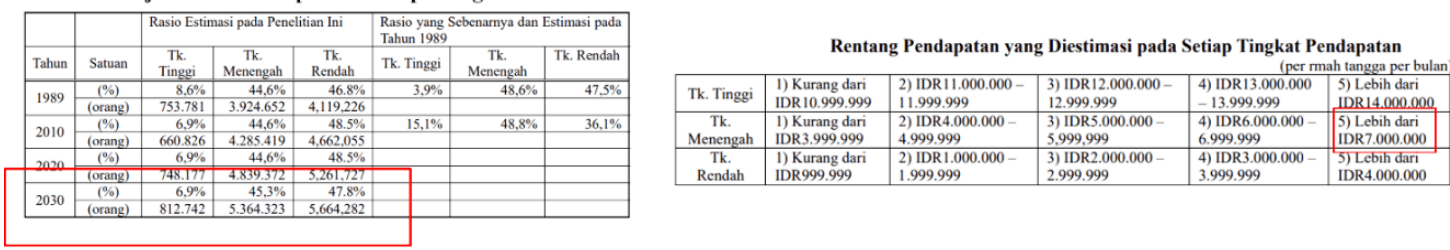

Sumber: https://databoks.katadata.co.id/

\section{KAJIAN LITERATUR}

\section{Ekologi}

Kata ekologi pertama kali diperkenalkan oleh Ernst Haeckel seorang ahli biologi Jerman pada tahun 1866. Menurut Ernst Haeckel ekologi adalah ilmu yang komprehensif yang memperlajari hubungan antar organisme dengan lingkungannya. Burdon-Sanderson menyatakan ekologi adalah ilmu yang mempelajari hubungan/relasi eksternal antar makhluk hidup, serta keberadaannya pada masa lampau dan masa kini. Ricklefs mendefinisikan ekologi sebagai ilmu 
lingkungan alam, terutama mempelajari hubungan mendalam antara makhluk hidup dengan lingkungan sekitarnya. Berdasarkan definisi-definisi di atas maka dapat disimpulkan bahwa ekologi adalah ilmu yang mempelajari hubungan timbal balik antar organisme atau organisme dengan lingkungannya. Ekologi bisa disebut sebagai ilmu dasar lingkungan, ilmu yang mempelajari makhluk hidup dalam rumah tangganya atau ilmu yang mempelajari seluruh pola hubungan timbal balik antara makhluk hidup sesamanya dengan komponen di sekitarnya. Ekologi menganut prinsip keseimbangan dan keharmonisan semua komponen alam.

\section{Beyond Ecology}

Pengertian dari "beyond" menurut kamus terjemahan (Cambridge Dictionary) adalah melebihi, melampaui sesuatu, melakukan sesuatu yang belum pernah dilakukan sebelumnya. Beyond ecology berarti sebuah tatanan/ sistem yang lebih baik dari sebelumnya, dalam segala aspeknya baik dari kehidupan makhluk hidup didalamnya maupun lingkungan alamnya baik fisik maupun non-fisik. Semuanya dibungkus dengan pemanfaatan teknologi yang sudah maju sekarang, demi percepatan dan keefisienan waktu.

\section{Pemanasan Global (Global Warming)}

Global warming merupakan sebuah isu perubahan iklim dunia yang disebabkan oleh emisi gas rumah kaca (greenhouse gas). Gas rumah kaca yang berlebihan di atmosfer bumi, menyebabkan memanasnya suhu di bumi berujung pada berbagai masalah yang menjulur kemana-mana. Berdasarkan data yang ada, pada dekade $2008-2018$ terukur kenaikan sekitar $1^{\circ} \mathrm{C}$ dibandingkan pada masa pra-industri (1850-1900), Dengan tingkat kenaikan temperaturnya sekitar $0,2^{\circ} \mathrm{C}$ per dekadenya, dimana pada 2020 mencapai $1,2^{\circ} \mathrm{C}$ lebih panas dibanding masa pra-industri. Berdasarkan laporan dari IPCC (Intergovernmental Panel on Climate Change) kenaikan suhu bumi berkisar antara $2-4,3^{\circ} \mathrm{C}$ dalam $50-100$ tahun kedepan, yang fatal bagi kehidupan di bumi.

\section{Greenhouse Gas - penyebab global warming}

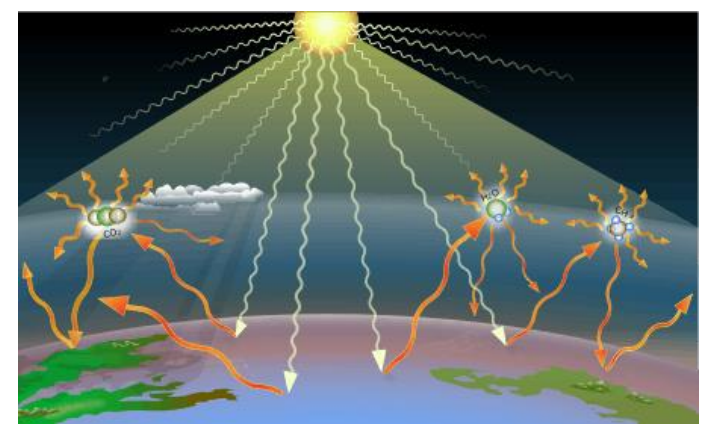

Gambar 1. Greenhouse Gas di Atmosfer Bumi, Menahan Panas Keluar Bumi Sumber: https://en.wikipedia.org/wiki/Greenhouse_gas

Gas rumah kaca (kadang-kadang disingkat $G H G$ ) adalah gas yang menyerap dan memancarkan energi radiasi dalam rentang inframerah termal, menyebabkan efek rumah kaca. Gas rumah kaca utama di atmosfer bumi adalah uap air ( $\mathrm{H} 2 \mathrm{O})$, karbon dioksida (CO2), metana (CH4), dinitrogen oksida (N2O), dan ozon (O3). Aktivitas manusia sejak awal Revolusi Industri (sekitar 1750) telah menghasilkan $45 \%$ peningkatan konsentrasi karbon dioksida di atmosfer, dari 280 ppm pada 1750 menjadi 415 ppm pada 2019. Konsentrasi karbon dioksida di atmosfer terakhir kali setinggi ini terjadi lebih dari 3 juta tahun yang lalu.

Efek yang disebabkan global warming:

\section{- Efek pada Cuaca}


- Curah hujan yang tidak teratur, daerah kering akan bertambah kering dan daerah basah akan bertambah basah

- Temperatur yang akan terus naik, hari-hari musim panas akan berjalan lebih lama

- Gelombang panas ekstrem - peningkatan resiko kebakaran dan masalah kesehatan

- Peningkatan intensitas Badai Tropis

\section{- Efek di daratan}

- Intensitas Banjir meningkat

- Kekeringan meningkat dalam intensitas dan jangka waktunya

- Kebakaran Hutan karena intensitas kekeringan yang lebih lama, seperti yang baru terjadi di Australia dan Kalifornia

\section{- Efek pada Cryosphere}

Cryosphere merupakan bagian-bagian planet yang sangat dingin, membeku dan tertutup salju atau es. Cryosphere, terutama daerah kutub, sangat sensitif terhadap perubahan iklim global. Mencairnya lapisan es Greenland dan Antartika Barat akan terus berkontribusi pada kenaikan permukaan laut dalam skala waktu yang lama.

\section{- Efek pada Lautan}

- Naiknya permukaan laut karena ekspansi termal dan pencairan gletser dan lapisan es, Studi menyatakan bahwa posibilitas kenaikan hingga tiga meter mungkin terjadi. Naiknya permukaan laut akan membahayakan ratusan juta orang di daerah pesisir dataran rendah di negara-negara seperti Cina, Bangladesh, India, dan Vietnam.

- Pemanasan permukaan laut. Lautan juga berfungsi sebagai penyerap karbondioksida, menyerap banyak karbon dioksida di atmosfer, karena konsentrasi $\mathrm{CO} 2$ yang berlebihan menyebabkan pengasaman laut $(\mathrm{pH}$ laut turun, menmyebabkan berkurangnya biodiversitas hewan, hancurnya terumbu karang)

- Meningkatnya suhu lautan, kemampuan laut untuk menyerap kelebihan CO2 menjadi berkurang

\section{- Efek pada Biodiversitas}

- Area Terrestrial (Daratan) dan Wetland (Area basah seperti rawa yang ada di daratan). Perubahan iklim telah diperkirakan menjadi pendorong utama hilangnya keanekaragaman hayati di hutan konifer yang sejuk, savana, sistem iklim mediterania, hutan tropis, dan tundra Arktik.

- Ekosistem Lautan

Terumbu karang air hangat sangat sensitif terhadap pemanasan global dan pengasaman laut. Terumbu karang menyediakan habitat bagi ribuan spesies dan jasa ekosistem seperti perlindungan pantai dan makanan.

\section{- Efek pada Manusia}

\section{- Food Security}

Perubahan iklim yang disebabkan oleh global warming akan mempengaruhi produksi makanan di seluruh dunia karena efek dari peningkatan $\mathrm{CO} 2$ di atmosfer: kenaikan temperatur, perubahan curah hujan, yang berpengaruh pada hal-hal lainnya. Dalam hal food security: tidak hanya membicarakan berapa banyak makanan yang tersedia, tetapi juga pengaruhnya terhadap kemudahan akses memperoleh makanannya, harga, kualitas dan kestabilan sistem produksi makanan kedepannya.

- Water Security 
Sumber air akan sangat dipengaruhi oleh perubahan iklim, yang diantaranya terjadi karena: curah hujan yang tak tentu, cryosphere dan kenaikkan permukaan air. Sumber air bersih akan sangat terpengaruh oleh perubahan temperatur (suhu), ketinggian air laut dan curah hujan yang ekstrim. Kenaikan suhu bumi akan mempengaruhi kenaikan air laut dan memperluas area pengaruh salinasi pada air tanah, yang merupakan sumber utama air bersih manusia.

- Kesehatan

- Efek langsung dari cuaca ekstrim, yang menyebabkan cedera dan hilangnya nyawa

- Efek tidak langsung, seperti kekurangan gizi yang disebabkan oleh gagal panen. Berbagai penyakit menular lebih mudah menular di iklim yang lebih hangat, seperti demam berdarah yang paling parah menyerang anak-anak, dan malaria.

- Menurut laporan dari United Nations Environment Programme dan International Livestock Research Institute, perubahan iklim dapat memfasilitasi terjadinya wabah Zoonosis, misalnya. penyakit yang ditularkan dari hewan ke manusia. Salah satu contoh wabah tersebut adalah pandemi COVID-19.

\section{Sumbangan Emisi Global Berdasarkan Sektor Ekonomi}

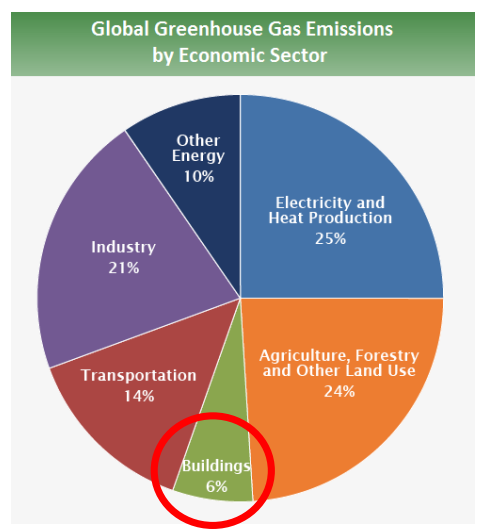

Gambar 2. Sektor Penghasil Emisi Gas Greenhouse

Sumber: https://www.epa.gov/ghgemissions/global-greenhouse-gas-emissions-data

Bangunan / Residensial (6\% dari emisi gas rumah kaca global). Sektor yang ingin difokuskan menjadi persoalan adalah bangunan/ residensial karena secara tidak langsung segala sesuatu yang kita lakukan sehari-hari menyumbang kepada kehancuran bumi di masa depan, juga sebagai fokus utama arsitektur. Emisi langsung dihasilkan dari aktivitas perumahan dan komersial dengan berbagai cara:

1. Pembakaran gas alam dan produk minyak bumi untuk kebutuhan pemanas dan memasak mengeluarkan karbon dioksida (CO2), metana ( $\mathrm{CH} 4)$, dan nitrous oksida (N2O). Emisi dari konsumsi gas alam mewakili 79,9 persen dari emisi CO2 bahan bakar fosil langsung dari sektor perumahan dan komersial pada tahun 2018. Konsumsi batu bara merupakan komponen kecil dari penggunaan energi di kedua sektor tersebut.

2. Sampah organik yang dikirim ke tempat pembuangan sampah mengeluarkan $\mathrm{CH}$.

3. Instalasi pengolahan air limbah mengeluarkan $\mathrm{CH} 4$ dan $\mathrm{N} 2 \mathrm{O}$.

4. Gas berfluorinasi (terutama hidrofluorokarbon, atau HFC) yang digunakan dalam sistem AC dan pendinginan dapat dilepaskan selama servis atau dari peralatan yang bocor. 
5. Emisi tidak langsung dihasilkan dengan membakar bahan bakar fosil di pembangkit listrik untuk menghasilkan listrik, yang kemudian digunakan dalam aktivitas perumahan dan komersial seperti penerangan dan peralatan rumah tangga.

\section{Makro - Indonesia}

Indonesia merupakan penghasil emisi gas rumah kaca terbesar keempat di dunia pada tahun 2015. Ekonomi Indonesia merupakan yang terbesar ke-16 di dunia dan terbesar di Asia Tenggara. Sumber emisi tertinggi berasal dari deforestasi dan kebakaran hutan gambut yang kemudian diikuti oleh emisi dari pembakaran bahan bakar fosil untuk energi.

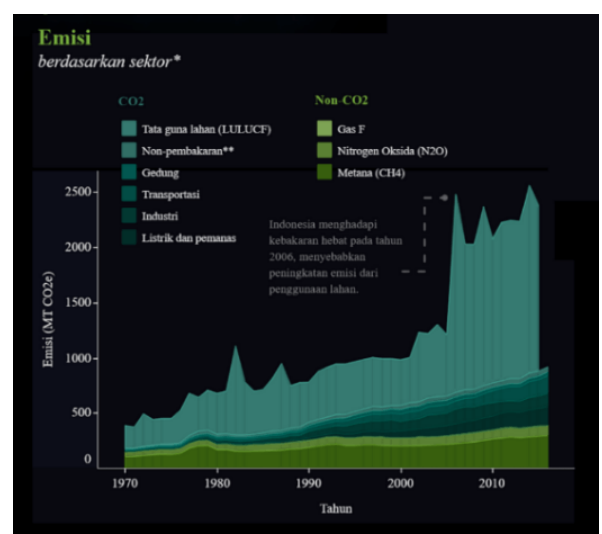

Gambar 3. Profil Karbon Indonesia

Sumber : https://www.carbonbrief.org/profil-carbon-brief-indonesia

Kesalahan tata guna lahan menyebar ke berbagai aspek, penyumbang terbesar berasal dari Pembakaran lahan gambut/ hutan untuk perluasan lahan. Kesalahan tata guna lahan yang juga besar adalah penyelewengan rencana/ tata ruang wilayah kota. Kesalahan tata guna lahan ini juga menjadi fatal karena permasalahannya akan menyebar ke arah limbah + energi.

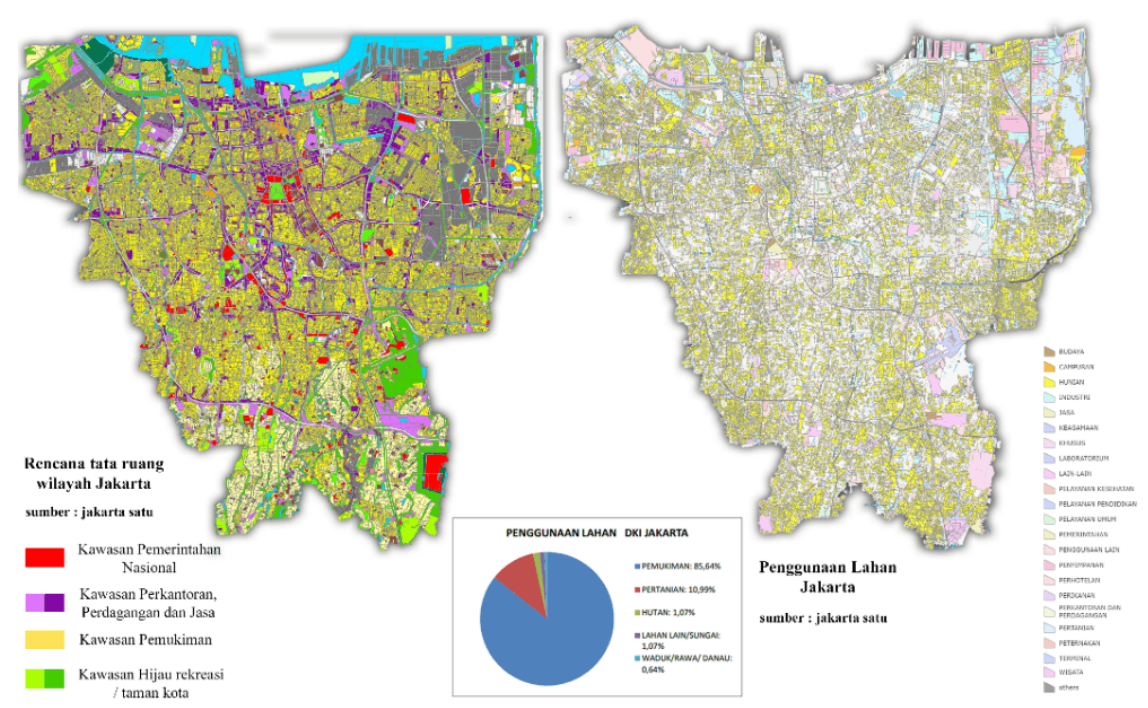

Gambar 4. Penggunaan Lahan Jakarta th. 2021

Sumber : https://jakartasatu.jakarta.go.id/

Kesalahan tata guna lahan terlihat dari persentase perumahan di Jakarta yang mencapai angka lebih dari $85 \%$, dimana penghijauan jauh dibawah angka optimal untuk kota yang sehat (30\%). 
Konsep - Target

Sustainable Development - No Carbon Facility, Self - Sustaining life (Menghasilkan semuanya sendiri, waste diolah). Tidak hanya memberi dampak baik kepada lingkungan hidup kita, tetapi juga mencoba menciptakan tren/ konsep kehidupan yang baru (self-sustaining life) melalui lingkaran terkecil kehidupan yaitu rumah dimana semuanya dimulai dan dijalankan dari rumah.

Proyek yang diusulkan adalah dalam bentuk Rusun (rumah susun), Rumah susun yang dikatakan disini hanya menggambarkan kategori/ jenis bangunannya, rumah susun (Rusun) tidak selalu diartikan sebagai rumah vertikal untuk masyarakat penghasilan rendah di daerah yang padat, Rusun disini hanya sebagai rumah yang dibangun secara vertikal. Bentuk rusun dipilih karena segala sesuatu kita mulai dari hal yang paling kecil/ sederhana begitu pula untuk menciptakan self-sustaining community ini perlu dimulai dari square 0 yaitu rumah kita.

\section{Rusun}

Rumah susun adalah bangunan gedung bertingkat yang dibangun dalam suatu lingkungan yang terbagi dalam bagian-bagian yang distrukturkan secara fungsional, baik dalam arah horizontal maupun vertikal dan merupakan satuan-satuan yang masingmasing dapat dimiliki dan digunakan secara terpisah, terutama untuk tempat hunian yang dilengkapi dengan bagian bersama, benda bersama, dan tanah bersama. (Undang-Undang Republik Indonesia Nomor 20 Tahun 2011, Pasal 1)

Jenis Rusun :

Rumah susun komersial adalah rumah susun yang diperuntukkan bagi masyarakat yang memiliki kemampuan ekonomi dan dapat diperjual belikan sesuai dengan mekanisme pasar. Contohnya adalah apartemen atau kondominium. Menjadikannya suatu proyek eksperimental yang bisa diterapkan secara lebih luas kedepannya.

\section{Komunitas Swasembada (Self-Sustaining Community)}

Rusun diciptakan untuk mewadahi komunitas masyarakat Swasembada (mandiri). Swasembada berarti mampu memenuhi kebutuhan sendiri tanpa bantuan orang lain sedangkan istilah komunitas berarti orang yang tinggal di satu tempat, seperti kabupaten atau kota dan dianggap sebagai sebuah keseluruhan (Oxford Advanced Dictionary, 2001). Tujuan Utama dari selfsustaining community ini adalah menghasilkan sebuah sistem komunitas dalam sebuah residensial/ tempat-tinggal yang tidak menghasilkan karbon. Menjadi swasembada total tidak mudah dicapai terutama di daerah perkotaan dibandingkan di pedesaan karena keterbatasan ruang untuk bertani dan beternak. Untuk mencapainya, berarti self-sustain system yang ada didalamnya harus bisa menghasilkan semua kebutuhan utama manusia yang tinggal di dalamnya makanan (baik sayuran maupun kebutuhan protein), air, listrik, dan sebagainya serta meminimalisir carbon footprint dengan menyediakan segala kebutuhan penghuni di dalamnya pada satu area yang sama / setidaknya berdekatan.

Skema teknologi Self-Sustain System yang akan diterapkan :

\section{- Aquaponik}

Aquaponik merupakan sebuah alternatif menanam tanaman dan memelihara ikan dalam satu wadah. Proses dimana tanaman memanfaatkan unsur hara yang berasal dari kotoran ikan yang apabila dibiarkan di dalam kolam akan menjadi racun bagi ikannya. Lalu tanaman akan berfungsi sebagai filter vegetasi yang akan mengurai zat racun tersebut menjadi zat yang tidak berbahaya bagi ikan, dan suplai oksigen pada air yang digunakan untuk memelihara ikan. 


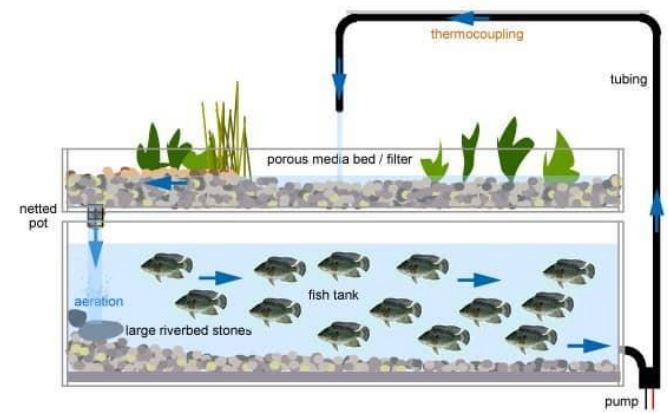

Gambar 5. Ilustrasi Sistem Aquaponik

Sumber: https://www.ayomenanam.net/2018/06/kelebihan-dan-kekurangan-budidaya-pertanian-

dengan-aquaponik.html

\section{- Rainwater Harvesting}

Teknik pengumpulan air hujan yang akan dipergunakan untuk keperluan hidup manusia. Salah satu cara praktikal untuk mengurangi pengeluaran untuk air bersih.

\section{- Sistem Rooftop Rainwater}

Air hujan juga dikumpulkan dari air yang terjatuh ke talang rumah dan dialirkan ke main tank. Air yang ada dalam main tank kemudian akan difilter lagi untuk keperluan lainnya. Untuk bisa diminum air perlu difilter khusus, sistemnya :

1. Sinar ultraviolet

2. Filter dan Disinfeksi

3. Klorin

4. Pasteurisasi surya

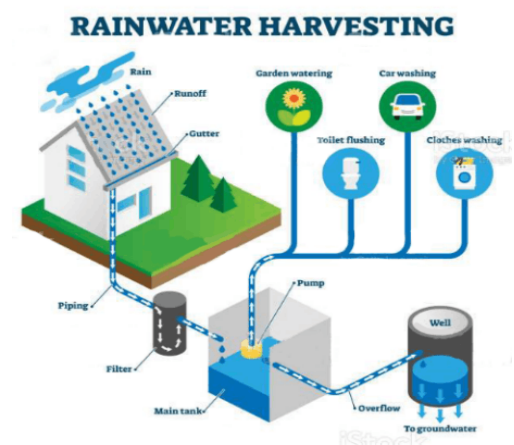

Gambar 6. Ilustrasi Rainwater Harvesting

Sumber : https://www.istockphoto.com/vector/rainwater-harvesting-system-isometric-diagramgm1201105579-344307644

\section{- Panel Surya}

Panel surya adalah sebuah sistem yang dapat digunakan untuk mengubah energi cahaya matahari menjadi energi listrik dengan menggunakan prinsip yang disebut efek photovoltaic. Energi listrik yang dihasilkan akan disimpan ke dalam sebuah baterai, kemudian digunakan untuk mengoperasikan perangkat elektronik sesuai kebutuhan listriknya. Sistem bisa berjalan meskipun di sore hari, malam hari, atau ketika kondisi hujan. Kekuatan energi listrik yang dihasilkan melalui panel surya bisa mencapai 250 Watt per meter perseginya.

\section{- Waste Management - sistem biogas}

Biogas merupakan gas yang dihasilkan oleh aktivitas anaerobik yang mendegradasi bahan-bahan organik. Contoh dari bahan organik ini adalah kotoran, limbah domestik, atau setiap limbah organik yang dapat diurai oleh makhluk hidup dalam kondisi 
anaerobik. Kandungan utama dalam biogas adalah metana dan karbon dioksida. Energi dari biogas dapat digunakan sebagai bahan bakar kendaraan maupun untuk menghasilkan listrik serta menghasilkan pupuk.

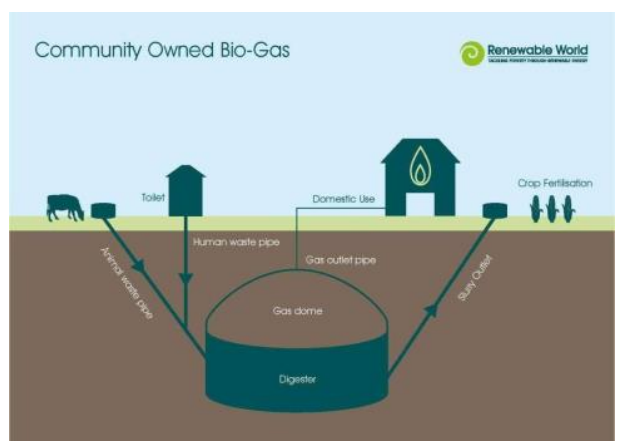

Gambar 7. Skema Sistem Biogas

Sumber: https://renewable-world.org/our-approach-to-renewable-energy/technologies/biogas-systems/

\section{- Grey Water Treatment}

Sistem permurnian bisa melalui sistem semacam septic-tank/ biotek - sand filter dan kemudian disimpan ke dalam tank, yang dari sini dipergunakan untuk keperluan yang nonkonsumsi (mis : untuk flush toilet, sumber air bagi tanaman, dll). Greywater yang sudah difilter akan dipergunakan untuk kebutuhan aquaponik.

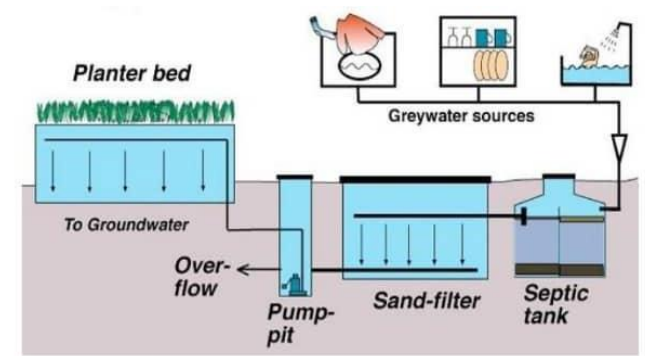

Gambar 8. Sistem Grey Water Treatment Sumber : ResearchGate

\section{- PCM SYSTEM (Phase Change Material)}

Sistem PCM (Phase Change Material) memanfaatkan energi yang dihasilkan dari senyawa yang cepat mencair dan cepat membeku, pada siang hari akan menghasilkan air dingin (hanya diperlukan sedikit udara panas, maka material akan meleleh dan melepas dingin) dan pada malam hari material akan membeku hanya karena sedikit udara dingin yang masuk dan memasuki masa istirahat (resting) yang kemudian fase akan diulang kembali pada siang hari.

Sistem PCM diperkirakan akan bekerja selama $63 \%$ sepanjang tahunnya, diperkirakan bisa menghemat hingga $70 \%$ listrik penggunaan $\mathrm{AC}$.

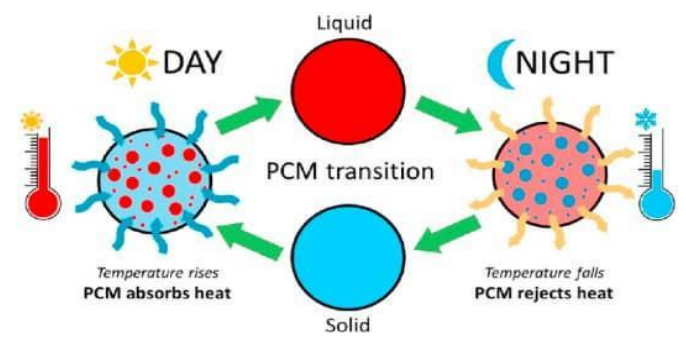

Gambar 9. Skema Kerja Sistem PCM pada Siang - Malam Hari Sumber: https://www.sciencedirect.com/science/article/pii/S2352710220337542 


\section{METODE}

\section{Metode Desain Kontekstual}

Metode ini menekankan bahwa sebuah bangunan harus mempunyai kaitan dengan lingkungannya.

\section{Prinsip Sustainable / Green Development, Penerapan Teknologi dalam Arsitektur}

- Memanfaatkan matahari dan lokasi untuk pemanasan alami, pendinginan, dan pencahayaan alami

- Desain Lansekap dengan tanaman asli yang tahan kering dan praktik hemat air

- Kualitas bangunan, struktur tahan lama

- Insulasi dan ventilasi yang tepat dan akurat

- Menggunakan teknologi hemat energi

4. DISKUSI DAN HASIL

Penentuan Lokasi - Lokasi Rusun

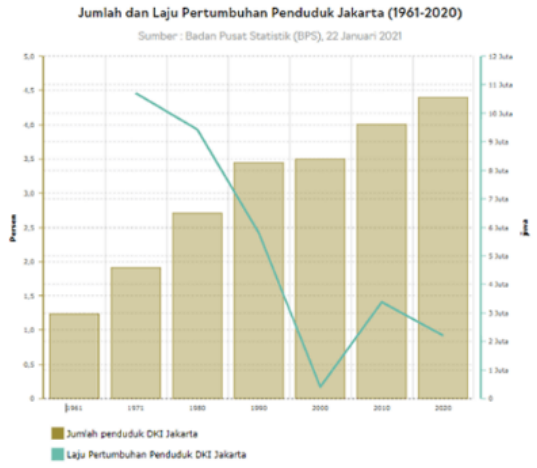

Gambar 10. Grafik Laju perumbuhan penduduk

Sumber : BPS, 2020

Kepadatan penduduk DKI Jakarta saat ini mencapai $16.704 \mathrm{jiwa} / \mathrm{km}^{2}$, bandingkan dengan kepadatan penduduk Indonesia yang hanya $141 \mathrm{jiwa} / \mathrm{km}^{2}$ (hasil dari proyeksi penduduk tahun 2020 dibagi dengan luas daratan Indonesia) ditambah dengan kepadatan penduduk Jakarta yang berkembang pesat setiap tahunnya menjadikan Jakarta tidak ideal lagi untuk ditempati Jakarta terbukti mempunyai kepadatan penduduk setara dengan 118 kepadatan nasional Indonesia.

Dengan kepadatan yang sudah melampaui batas, penambahan area pemukiman/ residensial di Jakarta hanya akan memperparah keadaan yang sudah ada (pengurangan area hijau, meningkatkan kepadatan lebih lagi, dll) maka diputuskan pengambilan tapak dengan lokasi diluar kota Jakarta ditambah dengan pertimbangan lainnnya yaitu harga tanah yang lebih terjangkau. 


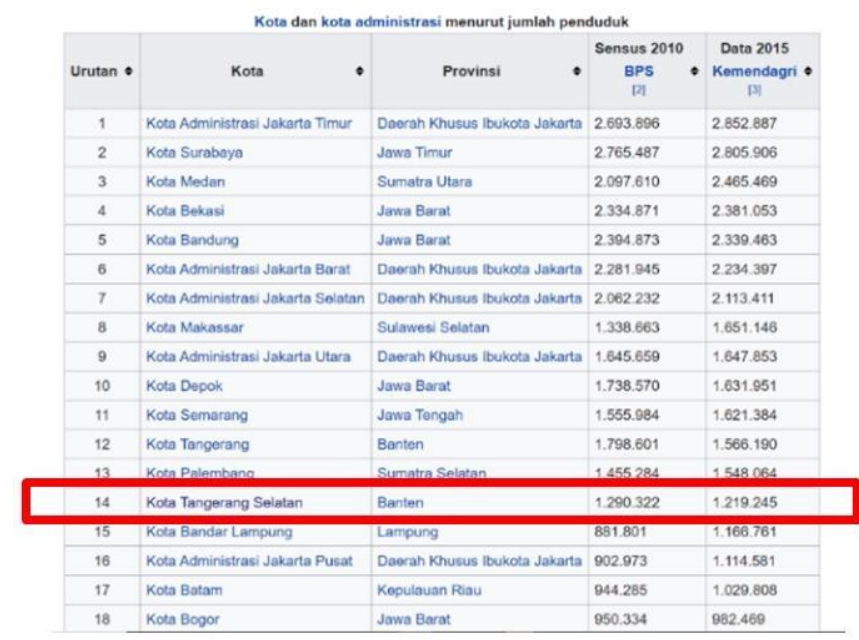

Gambar 11. Tabel Kepadatan jumlah penduduk

Sumber : https://id.wikipedia.org/wiki/Pembagian_administratif_Indonesia

Kota Tangerang Selatan memiliki kepadatan yang paling rendah ketimbang kota satelit lainnya dan juga didominasi peruntukannya untuk perumahan.
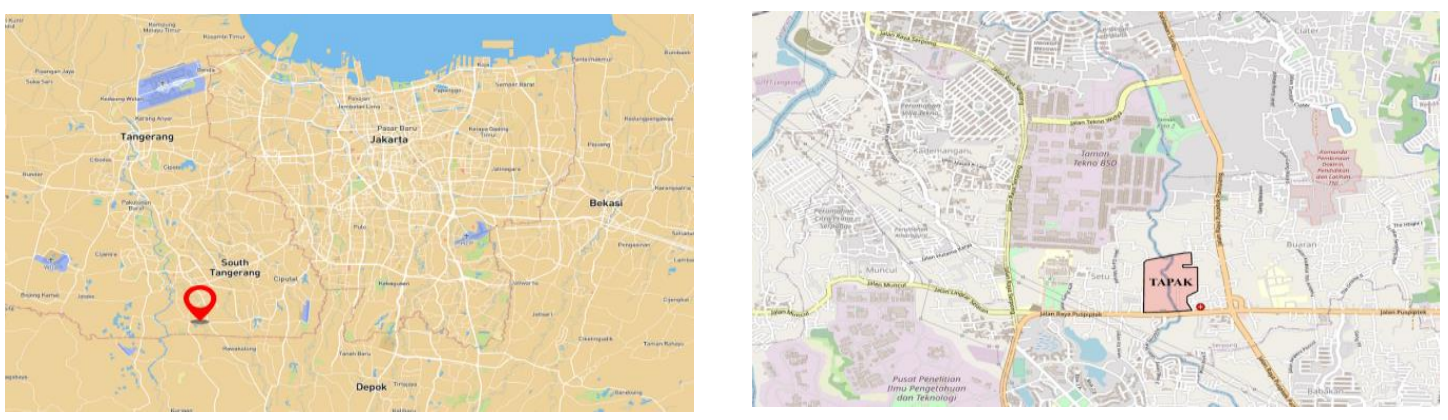

Gambar 10. Lokasi Tapak

Sumber : Dokumentasi Pribadi, 2021

Tapak berada di pinggiran Tangerang Selatan, berbatasan dengan kabupaten Bogor, Lokasi Tapak :

Jl. Puspiptek, Setu, Tangerang Selatan. Luas Tapak : $36.889 \mathrm{~m}^{2}$, KDB : 60\%, Tinggi Lt. : 7-10
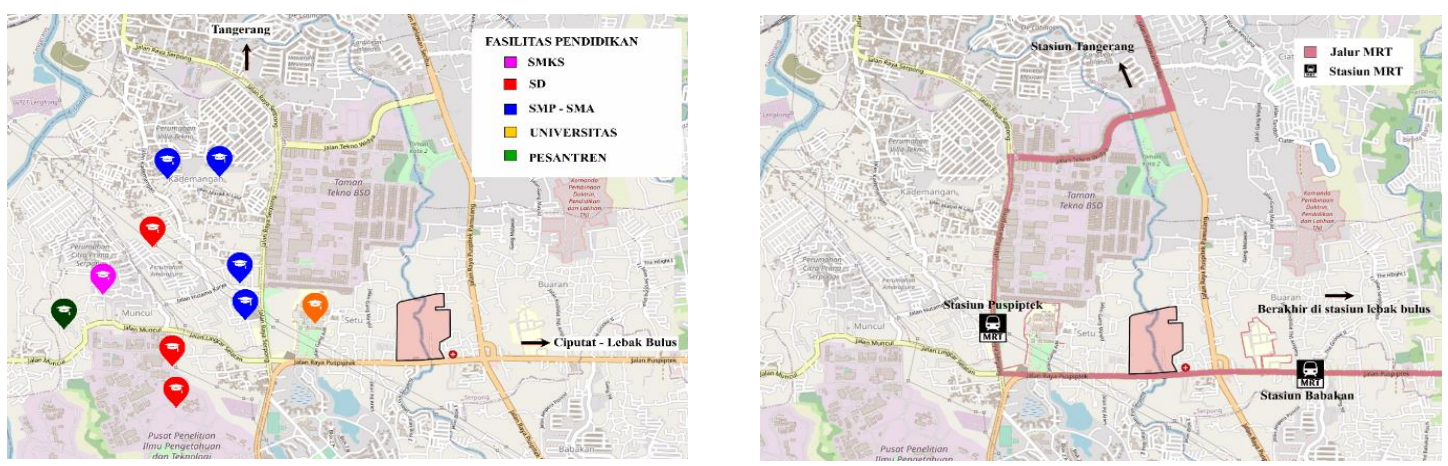

Gambar 12. Fasilitas sekitaran tapak

Sumber: Dokumentasi Pribadi, 2021

Pertimbangan perkembangan kedepannya dimana tapak dekat dengan jalur MRT yang menghubungkan langsung ke Lebak Bulus, Jakarta Selatan Fasilitas terpenting pendukung Rusun, Fasilitas pendidikan sekitar tapak yang ternyata cukup lengkap. 


\section{Definisi Proyek}

Menciptakan proyek eksperimental berupa perumahan vertikal (RUSUN) dimana penghuninya dapat memproduksi kebutuhan primernya untuk kegunaan sendiri, mulai dari pangan (sayuran, hewan, buah), air, listrik, gas melalui fasilitas yang disediakan untuk dipakai dan diusahakan bersama-sama sebagai sebuah komunitas. Melalui sistem yang ada, perumahan vertikal ini juga tidak menghasilkan karbon sama sekali, dimana semuanya dihasilkan sendiri dengan memanfaatkan energi alam dan adanya pengolahan waste yang dihasilkan. Melalui fasilitas eksperimental ini, diharapkan menjadi contoh untuk pengembangan perumahan kedepannya dan bisa menjamin keberlanjutan/ keberlangsungan hidup kita sebagai manusia serta keberlanjutan bumi kita secara keseluruhan.

\section{Sasaran}

- Masyarakat menengah - atas, baik warga Jakarta maupun Tangerang Selatan

- Masyarakat menengah - atas, yang tinggal di Jakarta maupun Tangerang Selatan tetapi bekerja di Jakarta (Komuter)

Tangerang selatan juga menjadi tempat yang cocok untuk rusun dikarenakan jumlah komuter (tinggal di Tangsel dan bekerja di Jakarta) mencapai $20 \%$ dari total warganya.

\section{Program}

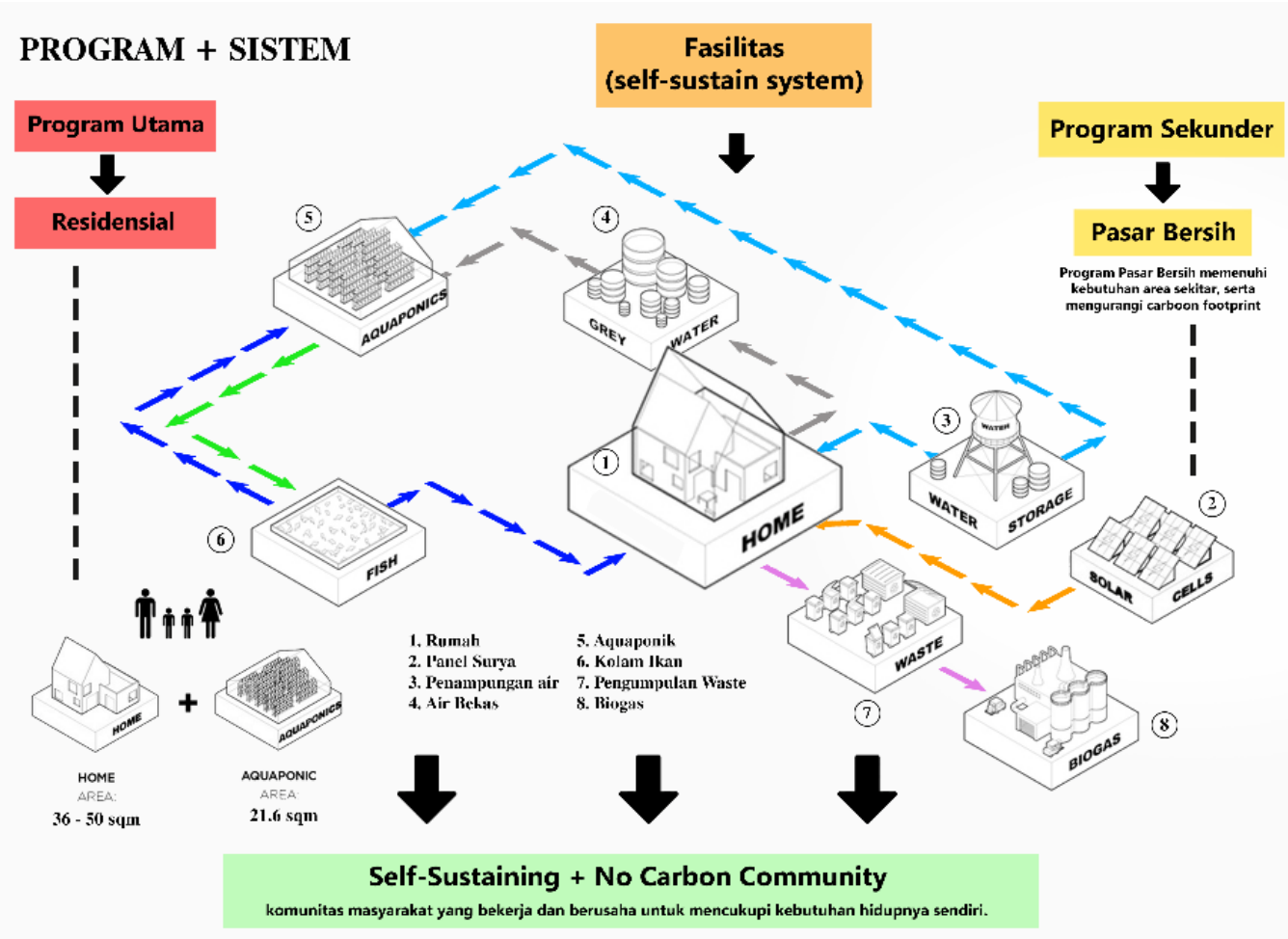

Gambar 13. Penjabaran Program Rusun

Sumber: Dokumentasi Pribadi, 2021 


\section{Perspektif}
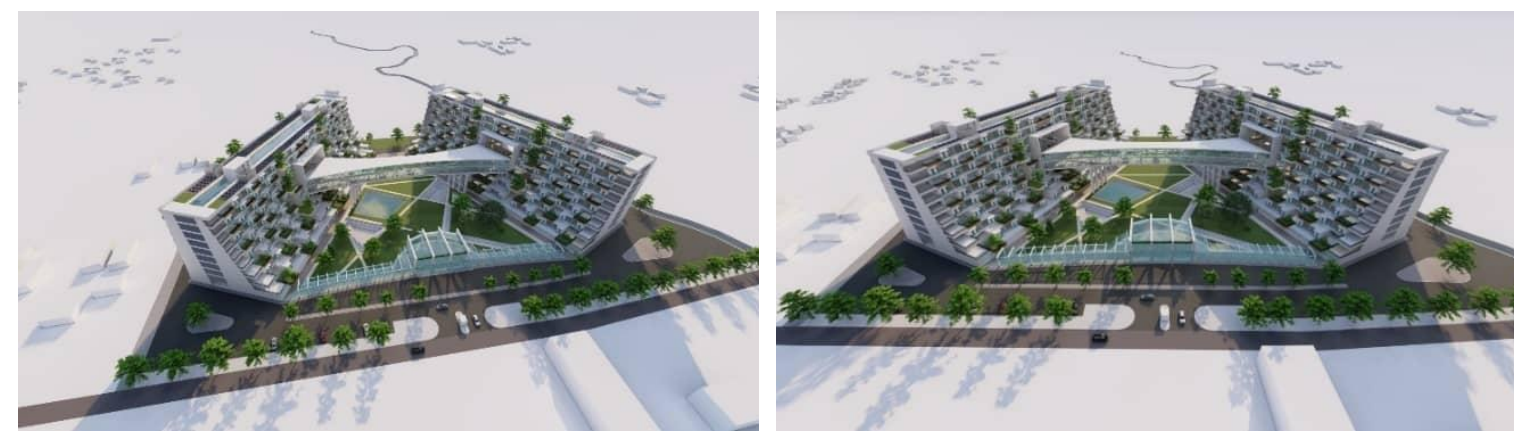

Gambar 14. Perspektif 3D Eksterior

\section{Konsep}

Sumber: Dokumentasi Penulis, 2021
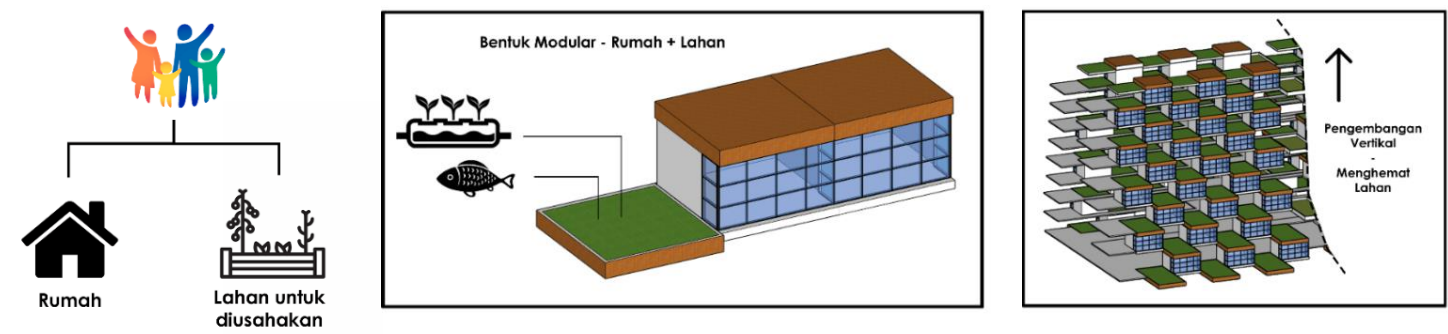

Gambar 15. Konsep Bangunan Rusun

Sumber: Dokumentasi Penulis, 2021

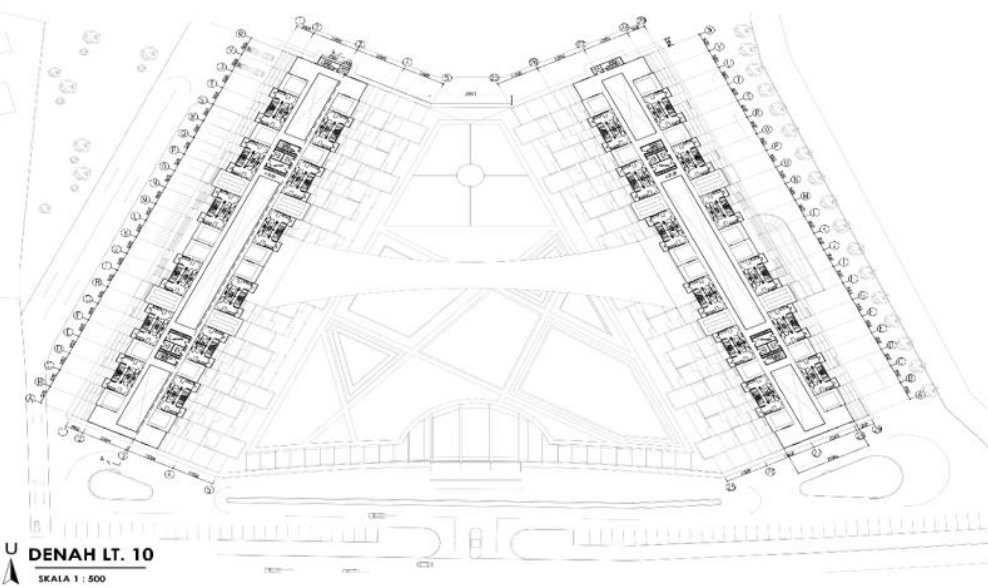

Gambar 16. Denah Lt. Tipikal

Sumber: Dokumentasi Penulis, 2021

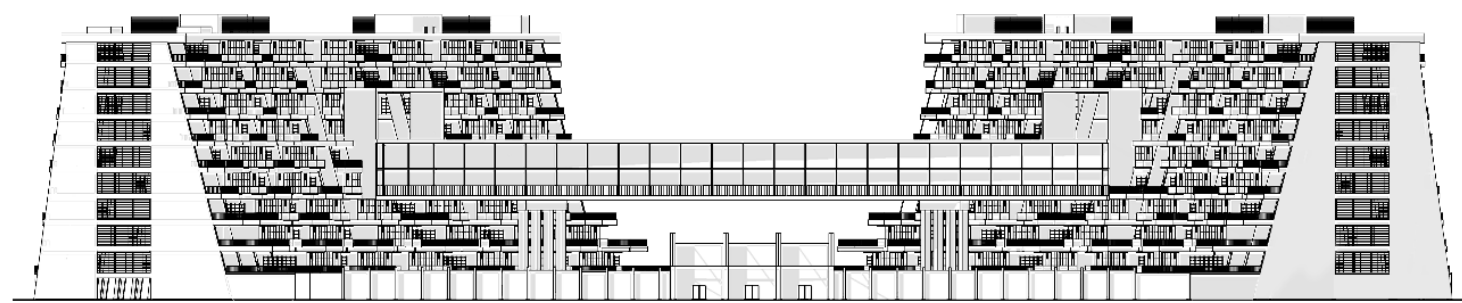

TAMPAK DEPAN

Gambar 17. Tampak Kanan dan Kiri

Sumber: Dokumentasi Pribadi, 2021 


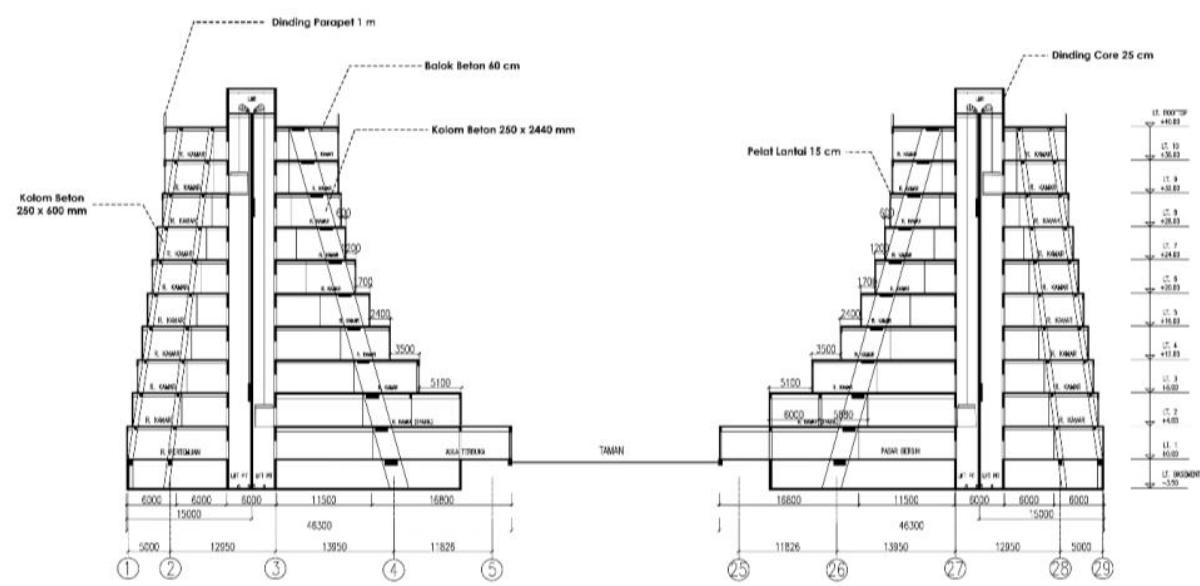

POTONGAN B-B

Gambar 18. Potongan B-B

Sumber: Dokumentasi Pribadi, 2021

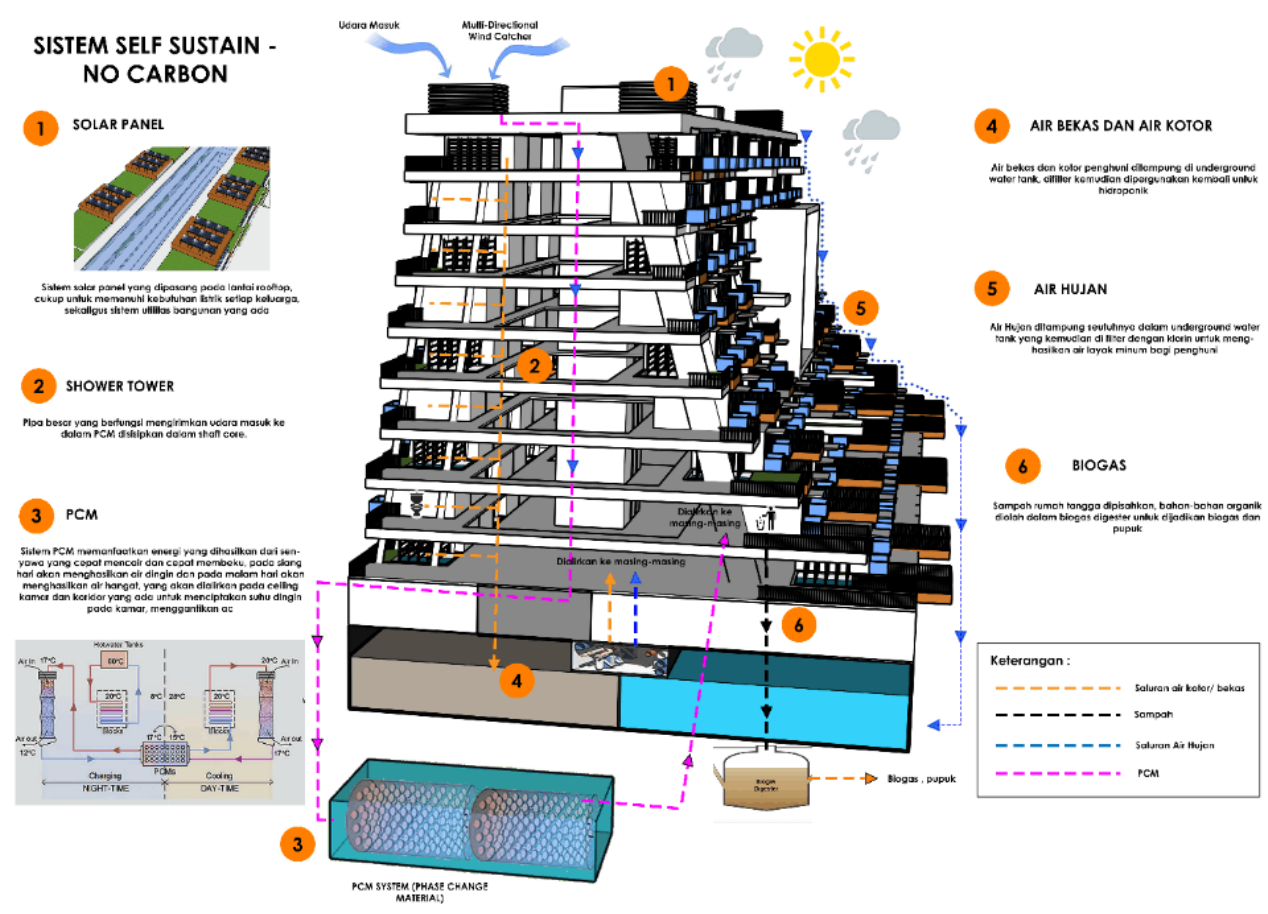

Gambar 19. Overview Sistem Self-sustain - No Carbon

Sumber: Dokumentasi Pribadi, 2021

Luas Tapak : $36.889 \mathrm{sqm}$

Luas Tapak Bangunan : 11.563 sqm (31.34\%)

Luas Total Bangunan : 59.418 sqm
1 Blok : 204 kamar ( Tipikal 1 blok : 100 kamar)

3.6 Ha : 408 kamar (Tipikal 3.6 Ha : 360 kamar)

Efektifitas rusun terbukti cukup baik walaupun diberikan banyak ruang untuk taman aquaponik, pada umumnya Rusun secara general untuk $1 \mathrm{HA}$ lahan = 100 kamar (1 blok), maka untuk 3,6 $\mathrm{HA}=360$ kamar.

Efektifitas Rusun No Carbon: 3,6 HA = 2 Blok $=408$ kamar 


\section{KESIMPULAN DAN SARAN KESIMPULAN}

Proyek ini bertujuan untuk menciptakan sebuah proyek eksperimental, sebuah prototipe bangunan perumahan vertikal masa depan yang lebih ramah lingkungan (tidak menghasilkan karbon keluar dari bangunan) dan dengan sistem bangunan tercipta kehidupan swasembada (menghasilkan segala kebutuhan sendiri) bagi penghuninya. Perubahan sistem perumahan yang konvensional penting untuk diubah dikarenakan begitu besarnya sumbangan bangunan dalam penghasilan emisi greenhouse gas secara global. Diharapkan ide, semangat, desain dari proyek ini bisa tersalurkan untuk kedepannya agar permasalahan pemanasan global bisa diselesaikan/ berkurang intensitasnya.

\section{SARAN}

Proyek ini tentu jauh dari kata sempurna, diperlukan penerapan sistem-sistem lebih lanjut terkait sistem green development/ sustainable developmentnya. Perkembangan selanjutnya bisa menjalar kepada teknologi konstruksi, transportasi, dan lainnya.

\section{REFERENSI}

A Complete Guide To Solar Panel Output (2021). https://www.linquip.com/blog/a-completeguide-to-solar-panel-output/

Buckhori, D. (2017). Definisi Ekologi. http://damayanti.staff.ipb.ac.id/files/2012/09/Pen dahuluan.pdf

Carbon Brief. "Profil Carbon Brief: Indonesia | Carbon Brief." (2019), https://www.carbonbrief.org/profil-carbon-brief-indonesia.

Change, Intergovernmental Panel on Climate (2018). Global Warming of $1.5^{\circ} \mathrm{C}$.

Cook, B. I., et al (2018). "Climate Change and Drought: From Past to Future."

Fraga, R. \& Burg, O.T. (2006). Urban Sustainable. Catalonia.

IPCC (2019). Technical Summary.

Kwok, R., and D. A. Rothrock (2009). "Decline in Arctic Sea Ice Thickness from Submarine and ICESat Records: 1958-2008."

Maxwell-Gaines, C. "Rainwater Harvesting 101 | Your How-To Collect Rainwater Guide." https://www.watercache.com/education/rainwater-harvesting-101.

Myers, S. S., et al (2017). "Climate Change and Global Food Systems: Potential Impacts on Food Security and Undernutrition."

Nugroho, E., dan Sutrisno (2008).Budidaya Ikan dan Sayuran dengan Sistem Akuaponik. Penebar Swadaya : Jakarta.

PEMBUATAN BIOGAS DARI LIMBAH ORGANIK DAN PEMANFAATANNYA (2010). http://www.lontar.ui.ac.id/file?file=digital/131551-T+27594-Analisis+potensiTinjauan+literatur.pdf

The Spiritual Life ."Effects Of Global Warming." (2019), https://slife.org/effects-of-globalwarming/.

WMO UNEP (2020), https://www.ipcc.ch/site/assets/uploads/sites/4/2020/02/SPM_UpdatedJan20.pdf.

Wuttig, M, Raoux, \& Simone (2010). Phase Change Materials. Springer Science \& Business Media.

World Green Building Council ."What Is Green Building? | World Green Building Council.", https://www.worldgbc.org/what-green-building. 
